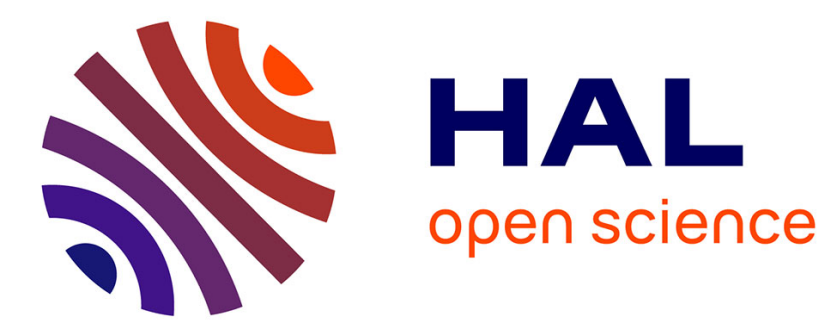

\title{
Chemical Vapour Deposition of AIN-Si3N4 Codeposits
}

\author{
F. Henry, B. Armas, C. Combescure, D. Thenegal, R. Flamand
}

\section{To cite this version:}

F. Henry, B. Armas, C. Combescure, D. Thenegal, R. Flamand. Chemical Vapour Deposition of AIN-Si3N4 Codeposits. Journal de Physique IV Proceedings, 1995, 05 (C5), pp.C5-785-C5-792. 10.1051/jphyscol:1995593 . jpa-00253955

\section{HAL Id: jpa-00253955 https://hal.science/jpa-00253955}

Submitted on 1 Jan 1995

HAL is a multi-disciplinary open access archive for the deposit and dissemination of scientific research documents, whether they are published or not. The documents may come from teaching and research institutions in France or abroad, or from public or private research centers.
L'archive ouverte pluridisciplinaire HAL, est destinée au dépôt et à la diffusion de documents scientifiques de niveau recherche, publiés ou non, émanant des établissements d'enseignement et de recherche français ou étrangers, des laboratoires publics ou privés. 
JOURNAL DE PHYSIQUE IV

Colloque C5, supplément au Journal de Physique U, Volume 5, juin 1995

\title{
Chemical Vapour Deposition of $\mathrm{AIN}_{-} \mathrm{Si}_{3} \mathrm{~N}_{4}$ Codeposits
}

\author{
F. Henry, B. Armas, C. Combescure, D. Thenegal and R. Flamand \\ Institut de Science et de Génie des Matériaux et Procédés, CNRS-IMP, BP. 5, Odeillo, 66125 Font Romeu \\ cedex, France
}

\begin{abstract}
A hot wall CVD reactor has been especially adapted to the problem of producing codeposits of aluminium and silicon nitrides. The experimental set-up for preparing "in situ" aluminium trichloride or a mixture of $\mathrm{AlCl}_{3}$ and $\mathrm{SiCl}_{4}$ by the action of silicon tetrachloride on an aluminium supply, heated to temperatures (Tc) between 380 and $520^{\circ} \mathrm{C}$ is presented. A study was also made of the deposition kinetics using a thermobalance with a continuous recording facility . The deposition kinetics of $\mathrm{AlN}$ and $\mathrm{Si}_{3} \mathrm{~N}_{4}$ were measured and compared. The codeposits prepared at a temperature of $1200^{\circ} \mathrm{C}$ and a total pressure of 1 Torr were found to be adherent when deposited on a graphite substrate covered by a layer of silicon carbide obtained by pyrolysis of tetramethylsilane at $1240{ }^{\circ} \mathrm{C}$. The deposits were characterized by a variety of methods : X-ray diffraction, wavelength dispersive spectroscopy and scanning electron microscopy.
\end{abstract}

\section{INTRODUCTION}

Aluminium nitride has been used in numerous electronic applications and as a high temperature oxidation resistant coating [1]. Thin solid films [2] of aluminium nitride can easily be produced by chemical vapour deposition. We have recently studied the resistance to oxidation of this material [3] which appears to be especially interesting at temperatures above $1000^{\circ} \mathrm{C}$.

Silicon nitride is also a material well known for its electrical properties and its highly refractory nature [4] [5]. In a previous study we have synthesized this compound by CVD using tetramethylsilane (TMS) and ammonia. The thermomechanical behaviour of the composite has been studied in a solar furnace with a high thermal flux [6].

More recently we have studied the Al-Si-N system in order to find new materials which exhibit a strong resistance to oxidation at high temperatures. A theoretical study has been made by other authors [7] to investigate the $\mathrm{Al}-\mathrm{Si}-\mathrm{N}$ system, considering it as a pseudo binary compound $\mathrm{AlN}-\mathrm{Si}_{3} \mathrm{~N}_{4}$. A more general study of the ternary system $\mathrm{M}-\mathrm{Si}-\mathrm{N}(\mathrm{M}=\mathrm{Al}, \mathrm{Cu}, \mathrm{Zn}, \ldots)$ has been made by other authors [8]. The results of this work have suggested that there is no ternary phase or solid solution present in the Al-Si-N system. An experimental study [9] of the Al-Si-N system has been made on codeposited nitrides of silicon and aluminium on silicon and sapphire substrates, at temperatures from 600 to $1100^{\circ} \mathrm{C}$ by ammoniolysis of aluminium trichloride and silane. The authors have shown that the deposition kinetics and thickness uniformity are influenced by the ratio $\mathrm{NH}_{3} /\left(\mathrm{AlCl}_{3}, \mathrm{SiCl}_{4}\right)$, but no thermodynamic study of the system was made.

In a previous study [10] we have successfully shown that it is possible to produce codeposits of aluminium and silicon nitrides using CVD. We have also made a thermodynamic study of the (Al, Si, N, $\mathrm{Cl}$ and $\mathrm{H}$ ) system and shown the influence of the experimental parameters.

In this study we have accomplished the "in situ" preparation of aluminium trichloride through the chemical action of silicon tetrachloride on an aluminium supply heated to a suitable (Tc) temperature. Furthermore, by varying the temperature of the aluminium supply, this technique has allowed us to obtain a mixture of two chlorides. A thermogravimetric system has also been adapted which made it able to follow changes in the deposition kinetics. 


\section{EXPERIMENTAL PROCEDURE}

\subsection{Experimental set-up}

Figure 1 shows the deposition system which was constituted by a hot wall reactor, and a vertical axis coupled to an automatic thermobalance used to continuously follow the variation in the mass of the substrate. The substrate was suspended from the arm of the thermobalance by a molybdenum wire. The vacuum was produced using a mechanical primary pump with an achievable limit of $10^{-3}$ Torr. A liquid nitrogen trap protected the pump by condensing byproducts of the gas phase reactions. The precursors were $\mathrm{SiCl}_{4}, \mathrm{AlCl}_{3}$ and $\mathrm{NH}_{3}$, with nitrogen as the carrier gas.

The substrates used were graphite covered with a layer of silicon carbide, obtained by pyrolysis of a mixture of tetramethylsilane (TMS) and hydrogen. The SiC layer acts as a diffusion barrier between the graphite substrate and the deposited nitrides so that adherent nitride layers can be formed.

The chlorides and ammonia were introduced separately to avoid reactions between them before the reactor inlet. The different flow rates were controlled using mass-flow controllers. The silicon tetrachloride was of $99.95 \%$ purity. Because its vapour pressure at room temperature is very low thus it was necessary to preheat the $\mathrm{SiCl}_{4}$ in a thermostat controlled bath at $40^{\circ} \mathrm{C}$ for vaporization .

The aluminium trichloride is a solid powder at room temperature and its vapour pressure is very low thus it is generally necessary to heat it and the flow control is very difficult. Therefore in this study the aluminium trichloride was prepared "in situ" by the action of $\mathrm{SiCl}_{4}$ on the aluminium supply by following reaction :

$$
4 \mathrm{Al}(\mathrm{s})+3 \mathrm{SiCl}_{4}(\mathrm{~g})---->4 \mathrm{AlCl}_{3}(\mathrm{~g})+3 \mathrm{Si}(\mathrm{s})
$$

In order to avoid condensation of $\mathrm{SiCl}_{4}$ and $\mathrm{AlCl}_{3}$, all the gas lines and mass flow controllers were insulated maintaining an internal system temperature of $50^{\circ} \mathrm{C}$. The high temperature valve is heated (see caption Figure 1) at $180^{\circ} \mathrm{C}$.

\subsection{Aluminium supply testing}

The use of a solid aluminium supply allowed us to vary the composition of the gaseous mixture as a function of the supply temperature (Tc) from pure $\mathrm{SiCl}_{4}$ to pure $\mathrm{AlCl}_{3}$, varying the ratio of the two chlorides.

The aluminium supply was composed of a mixture of aluminium powder of $99 \%$ purity (grain size $100 \mu \mathrm{m}$ ) mixed with spherulites of alumina (grain size $400 \mu \mathrm{m}$ ), all encased in a silica tube which is itself encased in a stainless steel tube. A resistance coil wrapped around the stainless steel casing allowed the aluminium supply to be heated up to the desired temperature. The exact temperature (Tc) was controlled using a thermocouple (see Figure 1). The aluminium supply has been tested in the following manner :

- It was studied in the temperature range from 300 to $530^{\circ} \mathrm{C}$.

- An $\mathrm{SiCl}_{4}$ gas flow of $1 \mathrm{SCCM}$ was passed through the aluminium supply and the pressure maintained at 200 Torr by means of a nitrogen flow of 60 SCCM. chamber.

A high temperature valve controlled the connection between the aluminium supply and the reactor

The other experimental parameters were : ammonia flow rate $\mathrm{D}_{\mathrm{NH} 3}=3 \mathrm{SCCM}$, substrate temperature $T=1000{ }^{\circ} \mathrm{C}$, total reactor pressure $\mathrm{P}=1$ Torr. A graphite substrate of dimensions $10 \mathrm{~mm}$ diameter and $2 \mathrm{~mm}$ thickness was introduced into the reactor and coated with $\mathrm{SiC}$. The conditions of the $\mathrm{SiC}$ deposition were as follows : substrate temperature $\mathrm{T}=1240^{\circ} \mathrm{C}$, total reactor pressure $\mathrm{P}=1 \mathrm{~T}$ orr, hydrogen flow rate $\mathrm{DH}_{2}=100 \mathrm{SCCM}$ and tetramethylsilane flow rate DTMS $=4$ SCCM, with a deposition time of 10 minutes. These experimental conditions allowed us to obtain well crystallized, compact, SiC coatings of approximately $1 \mathrm{~mm}$ thickness. The deposition of $\mathrm{SiC}$ and nitride layers was made successively in order to avoid opening the reactor and contaminating the deposited layers.

After the $\mathrm{SiC}$ layer was deposited the temperature was lowered to $1000{ }^{\circ} \mathrm{C}$ and a series of experiments were made with the aluminium supply at different temperatures. Thus layers whose composition varied from pure $\mathrm{Si}_{3} \mathrm{~N}_{4}$ to pure AIN by changing the proportion of the two nitrides were obtained .

The deposits made were then analysed using electron microwaves by " Wavelength Dispersive Spectroscopy ( WDS ) ". Figure 2 shows a graphical representation of the composition variations (atomic percentage) as a function of aluminium supply temperature (Tc), between 300 and $530^{\circ} \mathrm{C}$. It can be 
concluded that the compositions of deposits vary with of aluminium supply temperature (Tc). It may be seen that the quantity of silicon decreases with an increase in supply temperature while the quantity of aluminium increases gradually with increasing supply temperature $(\mathrm{Tc})$. The characterizations (Xray,WDS) that the deposits are composed of a mixture of aluminium and silicon nitrides (see $\S 4$ ). The aluminium nitride AIN layer, has a corresponding atomic composition of $50 \% \mathrm{Al}$ at $50 \%$ nitrogen. Silicon nitride $\mathrm{Si}_{3} \mathrm{~N}_{4}$ has an atomic composition of $42.9 \% \mathrm{Si}$ and $57.1 \% \mathrm{~N}$. It can be seen that the quantity of nitrogen in the deposit decreases steadily when a transition is made from a $\mathrm{Si}_{3} \mathrm{~N}_{4}$-rich deposit to an AlN-rich deposit. However the stoichiometry of catings tends to be preserved. As Tc is increased the deposit becomes richer in AIN, which is produced by the enrichement of the gaseous phase with $\mathrm{AlCl}_{3}$. It may also be concluded that to obtain pure aluminium nitride it is necessary to work with a supply temperature greater than $500^{\circ} \mathrm{C}$.

These results indicate that the aluminium supply is effective for producing the desired codeposit. The changes observed in the composition of deposits were caused by variations in the temperature of the reactor and aluminium supply. However all compositions calculated were subject to a certain degree of error due to fluctuations in the reactor and supply temperature.

Before making a study of codeposits of $\mathrm{AlN}$ and $\mathrm{Si}_{3} \mathrm{~N}_{4}$ the deposition kinetics of the two component nitrides were studied separately in order to make quantitative comparisons.

\section{COMPARISON OF THE DEPOSITION KINETICS OF AIN AND Si $3 \mathrm{~N}_{4}$}

A comparison is made of the deposition rates of the two nitrides $\mathrm{AlN}$ and $\mathrm{Si}_{3} \mathrm{~N}_{4}$ measured at the same temperature. The deposition rates are plotted as a function of the partial pressure of chloride $\mathrm{PCl}_{\mathrm{Cl}}$ at the same temperature. $\mathrm{P}_{\mathrm{C}}$ represents the partial pressure of silicon chloride for the $\mathrm{Si}_{3} \mathrm{~N}_{4}$ deposit and of aluminium chloride for the AIN deposit. This comparison was made for several temperatures in the same range of deposition rates $(0-50 \mathrm{mg} / \mathrm{h})$.

The results of this comparative study (Figures 3 to 6 ) show that for all cases the aluminium nitride deposition is more significantly affected by changes in the partial pressure of chloride than $\mathrm{Si}_{3} \mathrm{~N}_{4}$. As the reactor temperature increase to $1250{ }^{\circ} \mathrm{C}$ the rate of deposition of $\mathrm{Si}_{3} \mathrm{~N}_{4}$ increases and that of AlN decreases, with the two deposition rates approaching on another.

At $1250^{\circ} \mathrm{C}$ it may be observed that while the deposition temperature increases, for a given gaseous phase composition the deposition rates of the two nitrides vary inversely. It has also been established from a previous thermodynamic study [10] that increasing the deposition temperature causes the deposition rate of AlN to decrease. It may therefore be concluded that codeposits of different compositions may also be produced from the same gas phase composition when the deposition temperature is varied.

\section{STUDY OF THE AIN AND $\mathrm{Si}_{3} \mathrm{~N}_{4}$ CODEPOSIT}

\subsection{Codeposit experimental kinetics}

The codeposits were deposited at a total pressure $P=1$ Torr, a reactor temperature $T=1200^{\circ} \mathrm{C}$, a silicon chloride flow rate $\mathrm{D}_{\mathrm{SiCl} 4}=1 \mathrm{SCCM}$, an ammonia flow rate $\mathrm{D}_{\mathrm{NH} 3}=3 \mathrm{SCCM}$ and a supply temperature Tc which was changed in order to produce codeposits of varying compositions.

A series of six samples has been made of various compositions in the range from pure AIN (a) to pure $\mathrm{Si}_{3} \mathrm{~N}_{4}(\mathrm{f})$. The preparation conditions of this series are summarized in Table 1 .

Table 1 : Experimental deposition rates (Ve, $\mathrm{Vb}$ ) for different values of aluminium supply temperature (Tc).

$\mathrm{Ve}:$ deposition rate $\mathrm{mg} / \mathrm{h}$ obtained from the sample weight measurement before and after deposition (see text).

$\mathrm{Vb}$ : deposition rate $\mathrm{mg} / \mathrm{h}$ continuously recorded by the thermobalance.

\begin{tabular}{|c|c|c|c|c|c|c|}
\hline Samples & $\mathrm{a}$ & $\mathrm{b}$ & $\mathrm{c}$ & $\mathrm{d}$ & $\mathrm{e}$ & $\mathrm{f}$ \\
\hline $\mathrm{Tc}\left({ }^{\circ} \mathrm{C}\right)$ & 494 & 450 & 416 & 394 & 366 & 40 \\
\hline $\mathrm{Ve}(\mathrm{mg} / \mathrm{h})$ & 15.1 & 9.5 & 9.1 & 6.9 & 3.1 & 1.5 \\
\hline $\mathrm{Vb}(\mathrm{mg} / \mathrm{h})$ & 19.0 & 14.9 & 14.4 & 11.4 & 6.2 & 5.0 \\
\hline
\end{tabular}

It should be noted that an AIN deposit was obtained at a corresponding supply temperature of $494{ }^{\circ} \mathrm{C}$. This temperature is much lower than expected, considering the results obtained at $1000^{\circ} \mathrm{C}$ from the aluminium supply as shown in Figure 2. The deposition rate Ve of the sample was calculated from the mass variations subtracting the mass contribution from $\mathrm{SiC}$ (obtained from a previous experimental measurement of $\mathrm{SiC}$ deposition rate). The deposition rate $\mathrm{Vb}$ obtained using the thermobalance recordings, is calculated from the mass increase of both the sample and the sample holder. 
For sample (f), a second mass flow controller and a separate gas line (Figure 1) allowed the introduction of silicon tetrachloride without contact with the aluminium supply. A nitrogen flow was maintained through the vessel containing the supply in order to insure convenient hydrodynamic conditions.

The rate recorded by the thermobalance allows easily calculation of the deposition rate Ve and is a very accurate method since it takes into account the weight gain by the molybdenum substrate support.

An increase in the supply temperature (Tc) produces an increase in the deposition rate Ve of AIN proportionally larger than expected, because $1 \mathrm{SCCM}$ of $\mathrm{SiCl}_{4}$ should lead to the formation of 1.33 $\mathrm{SCCM}$ of $\mathrm{AlCl}_{3}$ (reaction I). The deposition rates of the two pure nitrides give some explanation for the two nitrides codeposition mechanism.

The deposition rate $\mathrm{Ve}$ of $\mathrm{AlN}$ is approximately ten times greater than the deposition rate $\mathrm{Ve}$ of $\mathrm{Si}_{3} \mathrm{~N}_{4}$ (Table 1).

Therefore it can be suggested that the increase in AlN deposition rate caused by varying the supply temperature is the result of an increase in the rate of exchange (reaction I) and thus an enrichment of the gaseous phase in aluminium trichloride. The greater quantity of $\mathrm{AlCl}_{3}$ thus leads to more AIN in the codeposit. It can be concluded that as $T c$ is increased the rate of deposition increases passing from that of $\mathrm{Si}_{3} \mathrm{~N}_{4}$ to that of AlN.

\subsection{Codeposit composition}

The composition of samples was determined by W.D.S. analysis of several points along a polished cross section of the sample. The calculated compositions are summarized in table 2 , with all values given in atomic per cent. The values quoted for samples (a) to (f) show that the deposited nitrides have close to stoichiometric atomic ratios. The two extreme cases were also studied, in sample (a) contained less than 0.5 at \% silicon. Similary sample (f) did not reveal any traces of aluminium, indicating that these samples were of pure aluminium and silicon nitrides respectively, samples (b) to (e) being a mixture of these two nitrides.

Table 2 : Codeposit composition (at \%) determined by W.D.S. analysis of several points along a polished cross section of the sample.

\begin{tabular}{|c|c|c|c|c|c|c|}
\hline samples & $\mathrm{Tc}\left({ }^{\circ} \mathrm{C}\right)$ & $\mathrm{Al}(\mathrm{at} \%)$ & $\mathrm{Si}(\mathrm{at} \%)$ & $\mathrm{N}(\mathrm{at} \%)$ & $\mathrm{C}(\mathrm{at} \%)$ & $\mathrm{O}(\mathrm{at} \%)$ \\
\hline $\mathrm{b}$ & 450 & 40.9 & 3.6 & 46.1 & 4.8 & 4.6 \\
\hline $\mathrm{c}$ & 416 & 37 & 9.4 & 47.7 & 2.9 & 3 \\
\hline $\mathrm{d}$ & 394 & 30.3 & 14.5 & 48.6 & 1.8 & 4.8 \\
\hline $\mathrm{e}$ & 366 & 22.1 & 22.3 & 52.3 & 2 & 1.3 \\
\hline
\end{tabular}

The results displayed in Table 2 show that the quantity of Al decreases going from sample (b) to sample (e); this corresponds to the decrease in aluminium supply temperature $(\mathrm{Tc})$.

The same result has already been established, as discussed in section 2.2 , and also, as previously shown, the silicon content decreases with increasing aluminium supply temperature.

In conclusion the feasibility of this method for producing codeposits of AIN and $\mathrm{Si}_{3} \mathrm{~N}_{4}$ has been shown. The aluminium supply has been tested and this work clearly demonstrates that it is possible to control the composition of codeposits by varying the aluminium supply temperature.

The deposition rates measured illustrate that the thermodynamic results from our previous work [10] are not always in agreement with the conclusions of this experimental kinetics study.

A possible explanation for these disagreements is that the thermodynamic calculations assume the equilibrium of the system, considered as closed. However, the real system is open and kinetic limitations probably lead to a significant deviation from the thermodynamical equilibrium which is then not pratically reached in our experiments.

\subsection{Characterization of codeposits}

The crystalline structure of the deposits has been characterized using $\mathrm{X}$-ray diffraction techniques.

It was observed that as the quantity of silicon nitride in a given codeposit sample increased, the corresponding $\mathrm{X}$-ray diffraction peaks were broadened revealing an amorphous nature, by contrast, aluminium nitride-rich codeposits were well crystallized.

A previous high resolution transmission electron microscopy study [11] revealed that silicon nitriderich samples contained dispersed nanocrystals of aluminium nitride. Codeposit samples which were aluminium nitride-rich exhibited large aluminium nitride crystals again surrounded by amorphous silicon 
nitride. Electron diffraction studies confirmed the trends observed by X-ray diffraction. In the present work, the surfaces of $\mathrm{AlN}, \mathrm{Si}_{3} \mathrm{~N}_{4}$ and codeposits samples were examined using scanning electron microscopy (S.E.M.).

The surface morphology observed for the deposits made at $1200^{\circ} \mathrm{C}$ are shown in Figure 7 and 8 , representing coatings of aluminium and silicon nitride respectively. It was found that AlN layers were of a crystalline nature with well defined facets observed in the S.E.M. images. By contrast, the surface appearance of $\mathrm{Si}_{3} \mathrm{~N}_{4}$ samples was amorphous, as previously shown by X-ray diffraction studies. Figure 9 shows the image recorded for a codeposit sample (c), (see $\S 4$ ). The sample surface is composed of a type of "orange skin" with small crystals present. The corresponding chemical analysis of this sample indicated that it was composed mainly of aluminium nitride (ratio of Al/Si approximatly 4:1). However it exhibits a surface morphology which is more $\mathrm{Si}_{3} \mathrm{~N}_{4}$ like than AIN. It is thought that the presence of silicon nitride phase prevents the development of well defined AlN crystals. Figure 10 shows the surface of the codeposit whose composition corresponds about to $50 \%$ of aluminium nitride and $50 \%$ of silicon nitride. As with the previous sample, the surface mophology does not exhibit well defined crystals.

A cross section of codeposit (c) is presented in Figure 11, an image which shows the successive layers of the graphite substrate, the $\mathrm{SiC}$ layer and finally the codeposit of AlN and $\mathrm{Si}_{3} \mathrm{~N}_{4}$. It can be observed that there seems to be good adhesion between the differents layers and the graphite substrate. Figure 12 shows an $\mathrm{X}$-image of the same sample cross section illustrating the distribution of the elements aluminium and silicon throughout the cross section. The broadest strip contain both $\mathrm{Si}$ and $\mathrm{Al}$; this is the AIN and $\mathrm{Si}_{3} \mathrm{~N}_{4}$ codeposit. At the left side of the codeposit strip, the silicon X-ray micrography shows clearly a brightest strip due to the high Si concentration, and the aluminium X-ray micrography shows that this high Si concentration zone does not contains Al. Therefore, we could conclude that the brightest strip observed on the silicon X-ray micrography was caused by the presence of the silicon carbide film.

\section{CONCLUSION}

This study has clearly demonstrated that it is possible to prepare "in situ" $\mathrm{AlCl}_{3}$ or a mixture of alumunium trichloride and silicon tetrachloride using an aluminium supply heated to the appropriate temperature.

An experimental set-up consisting of a hot wall reactor coupled with a thermobalance allowed us to study the deposition kinetics $\mathrm{AlN}, \mathrm{Si}_{3} \mathrm{~N}_{4}$ deposits and codeposits of these two nitrides. The crystalline structure of the codeposit samples has been characterized using X-ray diffraction techniques, and only deposits having a strong concentration of AlN exhibited spectra with well defined peaks corresponding to aluminium nitride, whereas silicon nitride was always found to be amorphous under our experimental preparation conditions. The scanning electron microscopy examination of the surface of codeposits prepared at $1200^{\circ} \mathrm{C}$ allowed us to observe the morphological evolution of the surface as a function of composition, and showed that an increased presence of silicon nitride leads to a reduction in the size of the aluminium nitride crystals.

The results obtained in this study leads the way for the synthesis of other codeposits of aluminium and silicon nitride. It is thought that at very high temperatures (higher than $1300^{\circ} \mathrm{C}$ ) it should be possible to coprecipitate well crystallised aluminium and silicon nitrides, and not only that of aluminium nitride as it was the case in the present study. It is hoped that the thermomechanical and oxidation resistive properties of these codeposits will be studied.

Finally, in order to have a very good control of the codeposit composition, the reactant flow rates of both $\mathrm{SiCl}_{4}$ and $\mathrm{AlCl}_{3}$ have to be known precisely. Two independent gas inlets will then be used in the future, one for the $\mathrm{SiCl}_{4}$ and one for pure $\mathrm{AlCl}_{3}$ obtained by the complete conversion of $\mathrm{SiCl}_{4}$ on an aluminium supply heated up to $500^{\circ} \mathrm{C}$.

\section{Aknowledgements}

This work has been partially supported by the French Ministry of Defense. "Direction des Recherches et Etudes Techniques (Contrat DRET n ${ }^{\circ}$ 92/1210A/DRET)".

\section{References}

[1] Billy M., Jarrige J., Lecompte J.P., Mexmain J. and Yessah S., Rev. Chim. Minéral. , 29 (1982) 673.

[2] Aspar B., Rodriguez-Clemente R., Figueras A., Armas B. and Combescure C., J. of Crystal Growth 129 (1993) 56-66.

[3] Labatut C., Kharchi D., Aspar B., Sibieude F. and Armas B., J. European Ceram. Soc. , 13 (1994) 339-344.

[4] Mellottée H. and Delbourgo R., Bull. Soc. Fr. Céram., 102 (1974) 65-73. 
[5] Niihara K.and Hirai T., J. Mater. Sci. , 11 (1976), 593.

[6] Wang A., Thenegal D., Royere C., Dupuy C. and Armas B., J. de Physique, C 5, Suppl. 5, Tome 50, mai (1989) 353-362.

[7] Hillert M. and Jonsson S., CALPHAD, 16 (2) (1992) 199-205.

[8] Weitzer F., Remschnig K., Schuster J.C., Rogl P., J. Mater. Res., 8 (10) (1990) 2152- 2159.

[9] Zirinski S., Irene E. E., J. Electrochem. Soc., 125 (2) (1978) 305-314.

[10] Henry F., Armas B., Balat M., Berjoan R., Combescure C., J. de Physique IV, C3, Suppl II, .3 (1993) 519-526.

[11] Marti P., Henry F., Maze1 M., Armas B.and Sevely J., (This conference).

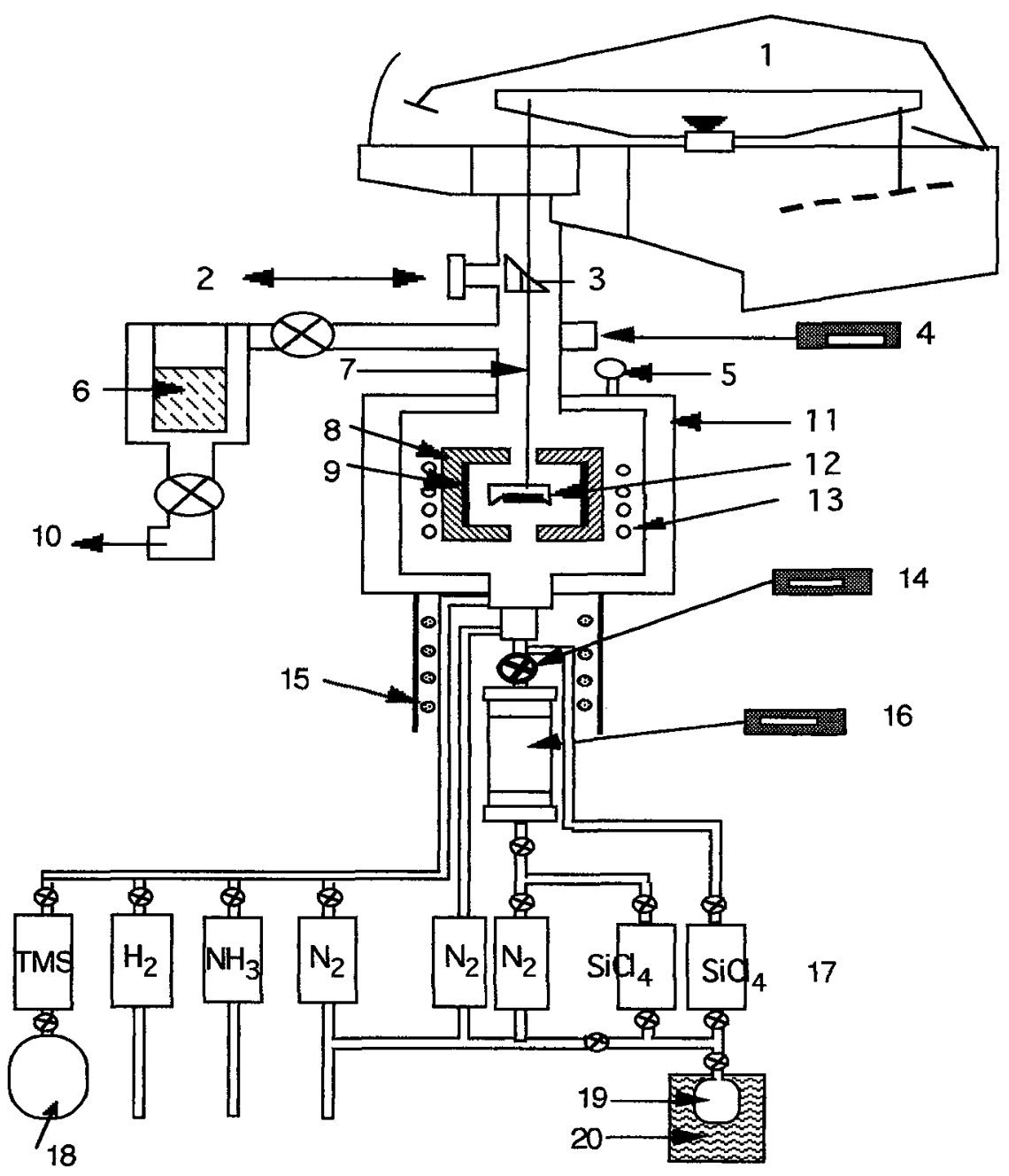

Figure 1: Experimental set up: (1) thermobalance, (2) to micropyrometer, (3) optical prism, (4) vacuum gauge, (5) Bourdon manometer, (6) liquid nitrogen trap, (7) Molybdenum wire, (8) graphite insulator, (9) graphite susceptor, (10) to vacuum pump, (11) reactor chamber, (12) substrate, (13) high frequency inductor, (14) high temperature valve controller, (15) high temperature valve heater, (16) Aluminium supply temperature controller, (17) mass flow controllers, (18) TMS evaporator, (19) $\mathrm{SiCl}_{4}$ evaporator, (20) thermostat controlled bath. 


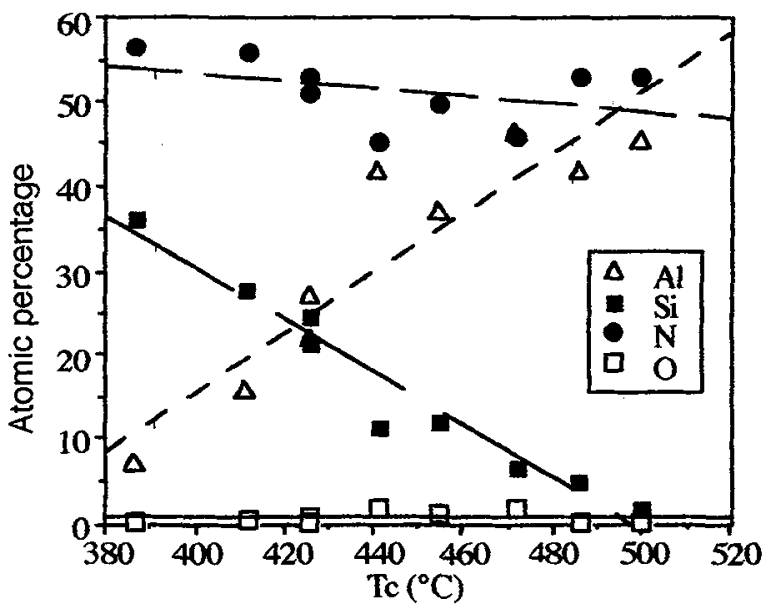

Figure 2: Codeposit composition vs Tc at $10 \mathrm{w}$ - $\mathrm{C}$.

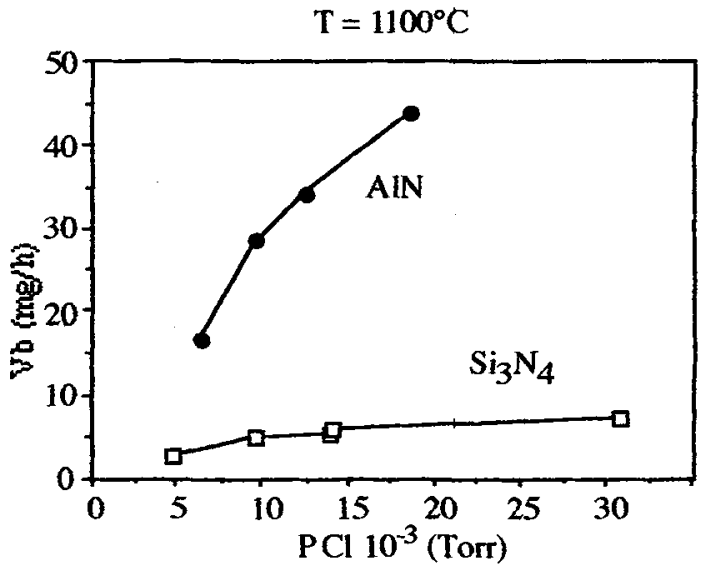

Figure 3: Deposition rate of $\mathrm{AlN}$ and $\mathrm{Si}_{3} \mathrm{~N}_{4}$ as a function of $\mathrm{Al}$ and Si chlorides partial pressures at $1100^{\circ} \mathrm{C}$.

$$
\mathrm{T}=1200^{\circ} \mathrm{C}
$$

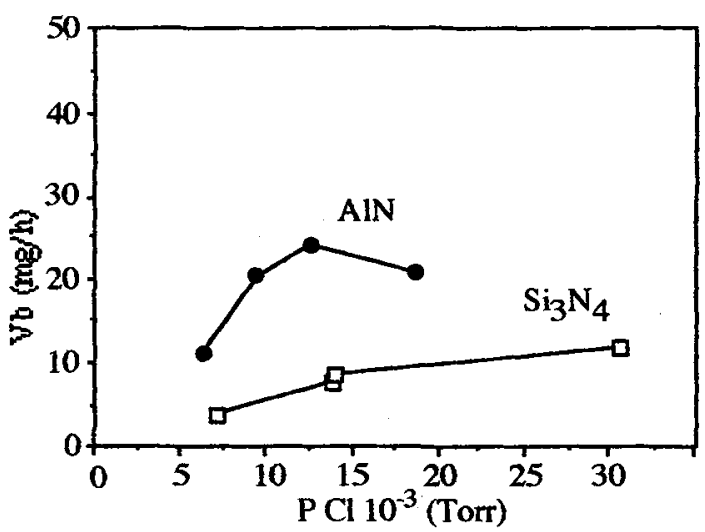

Figure 5: Deposition rate of $\mathrm{AlN}$ and $\mathrm{Si}_{3} \mathrm{~N}_{4}$ as a function of $\mathrm{Al}$ and $\mathrm{Si}$ chlorides partial pressures at $1200^{\circ} \mathrm{C}$.
$\mathrm{T}=1150^{\circ} \mathrm{C}$

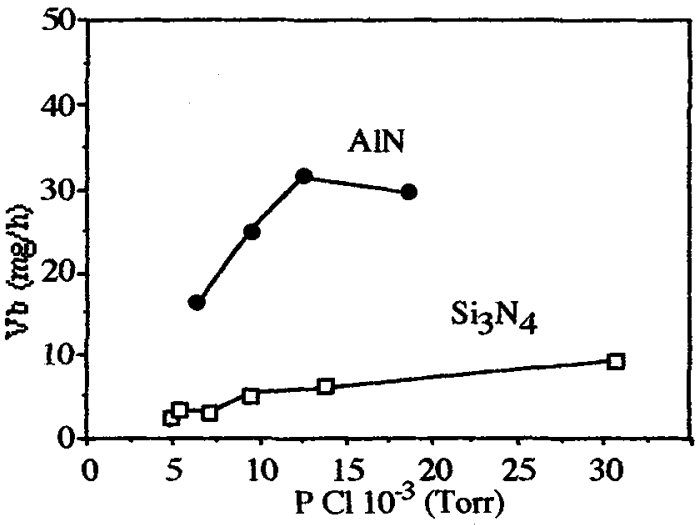

Figure 4: Deposition rate of $\mathrm{AlN}$ and $\mathrm{Si}_{3} \mathrm{~N}_{4}$ as a function of $\mathrm{Al}$ and $\mathrm{Si}$ chlorides partial pressures at $1150^{\circ} \mathrm{C}$.

$\mathrm{T}=1250^{\circ} \mathrm{C}$

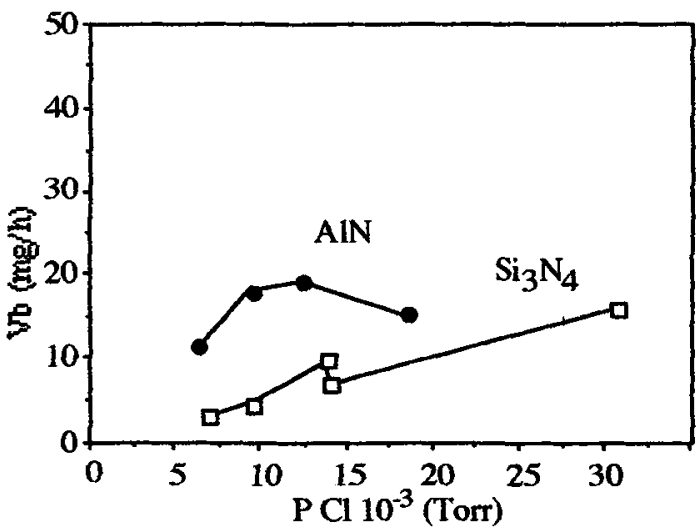

Figure 6: Deposition rate of $\mathrm{AIN}$ and $\mathrm{Si}_{3} \mathrm{~N}_{4}$ as a function of $\mathrm{Al}$ and $\mathrm{Si}$ chlorides partial pressures at $1250^{\circ} \mathrm{C}$. 


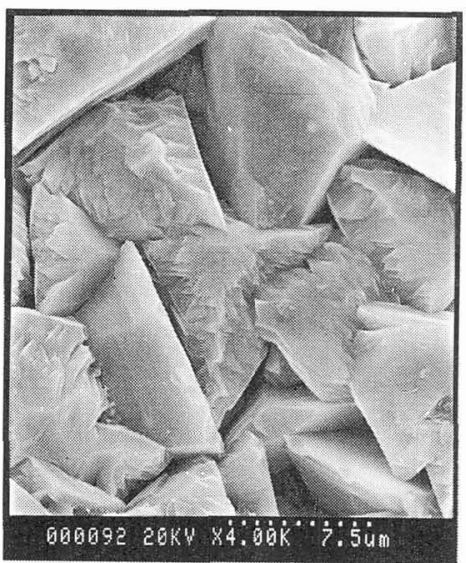

Figure 7: AlN prepared at $\mathrm{T}=1200^{\circ} \mathrm{C}$, total pressure $\mathrm{P}=1$ Torr.

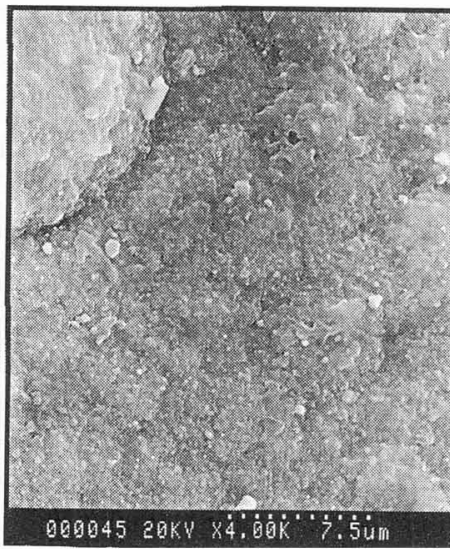

Figure 9 : AlN and $\mathrm{Si}_{3} \mathrm{~N}_{4}$ codeposit . Deposition conditions: $\mathrm{T}=1200^{\circ} \mathrm{C}, \mathrm{P}=1$ Torr, $\mathrm{Tc}=416^{\circ} \mathrm{C}$.

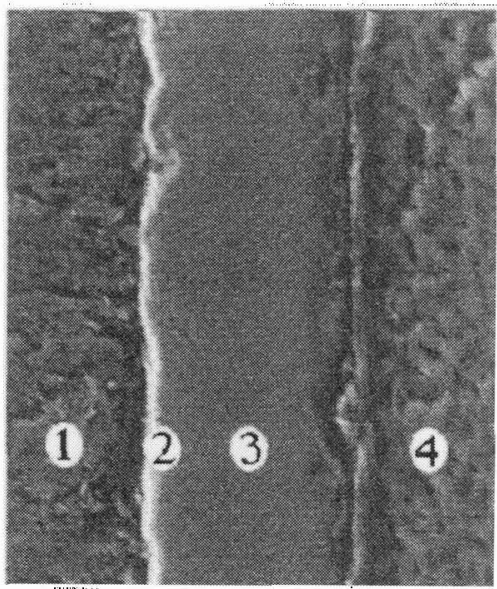

Figure 11 : Cross section ( electronic image) of the codeposit shown in Fig. 9: (1) graphite substrate, (2) $\mathrm{SiC}$ layer, (3) AIN and $\mathrm{Si}_{3} \mathrm{~N}_{4}$ codeposit, (4) resin.

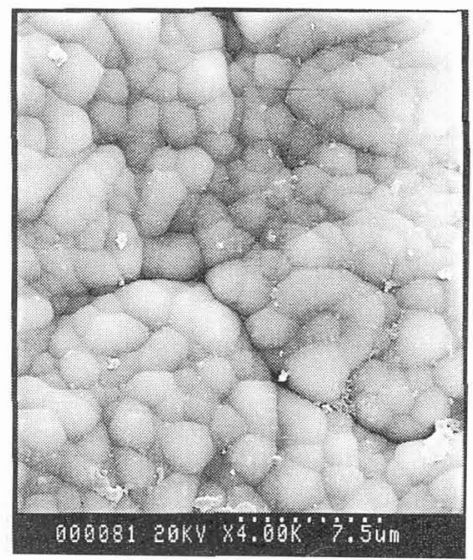

Figure 8: $\mathrm{Si}_{3} \mathrm{~N}_{4}$ prepared at $\mathrm{T}=1200^{\circ} \mathrm{C}$, total pressure $\mathrm{P}=1$ Torr.

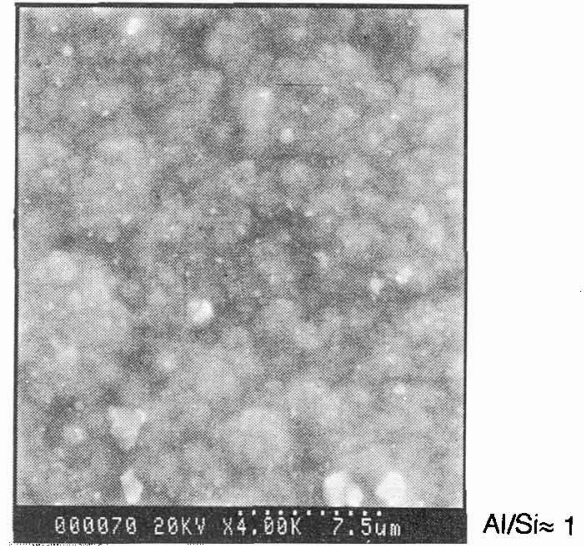

Figure 10:AlN and $\mathrm{SizN}_{4}$ codeposit . Deposition

conditions : $\mathrm{T}=1200^{\circ} \mathrm{C}, \mathrm{P}=1$ Torr, $\mathrm{Tc}=366^{\circ} \mathrm{C}$.

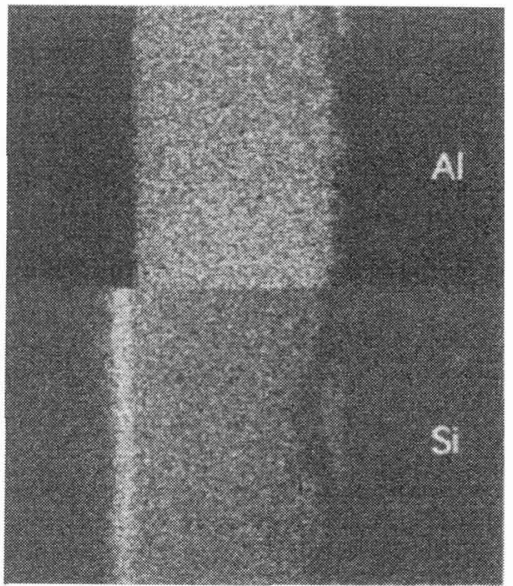

Figure 12: $X$ image of the sample in Fig. 11 illustrating the distribution of $\mathrm{Al}$ and $\mathrm{Si}$. 